\title{
GERMINATION AND VIGOUR IN SEEDS OF THE COWPEA IN RESPONSE TO SALT AND HEAT STRESS ${ }^{1}$
}

\author{
LUMA RAYANE DE LIMA NUNES ${ }^{2} *$, PALOMA RAYANE PINHEIRO ${ }^{2}$, CHARLES LOBO PINHEIRO $^{2}$, KELLY $^{2}$ \\ ANDRESSA PERES LIMA ${ }^{2}$, ALEK SANDRO DUTRA ${ }^{2}$
}

\begin{abstract}
Salinity is prejudicial to plant development, causing different types of damage to species, or even between genotypes of the same species, with the effects being aggravated when combined with other types of stress, such as heat stress. The aim of this study was to evaluate the tolerance of cowpea genotypes (Vigna unguiculata L. Walp.) to salt stress at different temperatures. Seeds of the Pujante, Epace 10 and Marataoã genotypes were placed on paper rolls $\left(\right.$ Germitest $\left.^{\circledR}\right)$ moistened with different salt concentrations of 0.0 (control), 1.5, 3.0, 4.5 and $6.0 \mathrm{dS} \mathrm{m}^{-1}$, and placed in a germination chamber (BOD) at temperatures of 20, 25, 30 and $35^{\circ} \mathrm{C}$. The experiment was conducted in a completely randomised design, in a $3 \times 4 \times 5$ scheme of subdivided plots, with four replications per treatment. The variables under analysis were germination percentage, first germination count, shoot and root length, and total seedling dry weight. At temperatures of 30 and $35^{\circ} \mathrm{C}$, increases in the salt concentration were more damaging to germination in the Epace 10 and Pujante genotypes, while for the Marataoã genotype, damage occurred at the temperature of $20^{\circ} \mathrm{C}$. At $25^{\circ} \mathrm{C}$, germination and vigour in the genotypes were higher, with the Pujante genotype proving to be more tolerant to salt stress, whereas Epace 10 and Marataoã were more tolerant to high temperatures. Germination in the cowpea genotypes was more sensitive to salt stress when subjected to heat stress caused by the low temperature of $20^{\circ} \mathrm{C}$ or high temperature of $35^{\circ} \mathrm{C}$.
\end{abstract}

Keywords: Vigna unguiculata. Physiological potential. Salinity. Tolerance.

\section{GERMINAÇÃO E VIGOR DE SEMENTES DE FEIJÃO-CAUPI EM RESPOSTA AOS ESTRESSES SALINO E TÉRMICO}

RESUMO - A salinidade é prejudicial ao desenvolvimento vegetal, causando diferentes danos às espécies, ou até mesmo entre genótipos da mesma espécie, com os efeitos sendo agravados quando combinado a outro estresse, como o térmico. Objetivou-se avaliar a tolerância ao estresse salino de genótipos de feijão-caupi (Vigna unguiculata L. Walp.) em diferentes temperaturas. As sementes dos genótipos Pujante, Epace 10 e Marataoã foram semeadas em rolos de papel (Germitest $\left.{ }^{\circledR}\right)$, umedecidos com diferentes concentrações salinas de 0,0 (controle); 1,$5 ; 3,0,4,5$ e $6,0 \mathrm{dS} \mathrm{m} \mathrm{m}^{-1}$, acondicionados em câmara de germinação (B.O.D.) nas temperaturas de $20,25,30$ e $35^{\circ} \mathrm{C}$. O experimento foi conduzido em delineamento inteiramente casualizado, em parcela subdividida no esquema de $3 \times 4 \times 5$, com quatro repetições por tratamento. As variáveis analisadas foram porcentagem de germinação, primeira contagem de germinação, comprimento da parte aérea e da raiz e massa seca total da plântula. Nas condições de temperaturas de 30 e $35^{\circ} \mathrm{C}$, o aumento da concentração salina foi mais prejudicial à germinação dos genótipos Epace 10 e Pujante, enquanto para o Marataoã isto ocorreu na temperatura de $20{ }^{\circ} \mathrm{C}$. Na temperatura de $25{ }^{\circ} \mathrm{C}$ a germinação e o vigor dos genótipos foram maiores, sendo que, o genótipo Pujante mostrou-se mais tolerante ao estresse salino, enquanto Epace 10 e Marataoã a temperaturas elevadas. A germinação dos genótipos de feijão-caupi foi mais sensível ao estresse salino quando submetidas ao estresse térmico, causado por temperatura baixa de $20^{\circ} \mathrm{C}$ ou elevada de $35^{\circ} \mathrm{C}$.

Palavras-chave: Vigna unguiculata. Potencial fisiológico. Salinidade. Tolerância.

\footnotetext{
${ }^{*}$ Corresponding author

${ }^{1}$ Received for publication in $05 / 29 / 2018$; accepted in $11 / 18 / 2018$.

${ }^{2}$ Department of Phytotecnic of the Center of Agricultural Sciences, Universidade Federal do Ceará, Fortaleza, CE, Brazil; lumanunes20@hotmail.com - ORCID: 0000-0001-7455-7897, palloma.ana@hotmail.com - ORCID: 0000-0002-0219-1483, charlesclp@yahoo.com.br - ORCID: 0000-0001-8111-7638, kellyandressah@hotmail.com - ORCID: 0000-0003-2789-8642, alekdutra@ufc.br-ORCID: 0000-0002-4298-383X.
} 


\section{INTRODUCTION}

The cowpea is a legume of great socioeconomic importance for the North and Northeast of Brazil, being a direct source of employment and an important staple food due to its high nutritional value (FREIRE FILHO et al., 2011). Faced with food shortages, the outlook for the crop is good, since its characteristics include hardiness, adaptability and precocity, with good production capacity in unfavourable environments (SOUZA et al., 2013).

Several authors have reported a decrease in cowpea production in the Northeast of Brazil, which can be explained by the saline soils and water found in the region, intensified by the high rate of evapotranspiration and low rainfall (FERREIRA et al., 2017; NASCIMENTO et al., 2017; OLIVEIRA et al., 2017). The species is considered moderately tolerant to salinity as it can withstand values for electrical conductivity of up to $3.3 \mathrm{dS} \mathrm{m}^{-1}$ for the irrigation water and $4.9 \mathrm{dS} \mathrm{m}^{-1}$ for the soil saturation extract (AYERS; WESTCOT, 1999).

Increases in the salt concentration of the soil solution may induce conditions of stress in the plant, mainly due to the fall in the water potential of the solution. As a result, water absorption is reduced, hampering cell expansion, since the pressure potential in the cell tends to match that of the soil (TAIZ et al., 2017). Excess salts also compromise the physiological and biochemical functions of plants and the use of essential nutrients due to the accumulation of toxic ions (CALVET et al., 2013).

Ionic toxicity can also lead to a delay in seedling emergence and even reduce seed viability, as it affects the physiological and metabolic processes of the embryonic tissue, delaying seed imbibition and root elongation (ESTEVES; SUZUKI, 2008); seedling growth is compromised due to the decrease in cellular expansion and elongation (MOTERLE et al., 2008).

Plants can be subjected to a combination of abiotic stress in the field, such as salinity and heat stress, which can have a devastating effect on plant development (TAIZ et al., 2017). Temperature is an important factor in the germination and development of plants, affecting different physiological processes, including photosynthesis, respiration and hormone levels. According to Marcos-Filho (2015), heat stress during the germination process can be evaluated from changes in germination percentage, speed and uniformity, since the temperature affects water absorption and the biochemical reactions necessary for germination to take place.

The aim of this study therefore, was to evaluate germination and vigour in seeds of three cowpea cultivars, submitted to different levels of salinity and temperature regimes.

\section{MATERIAL AND METHODS}

The experiment was conducted at the Seed Analysis Laboratory of the Centre for Agricultural Sciences (CCA), at the Federal University of Ceará, Pici Campus, in Fortaleza in the State of Ceará. Cowpea seeds of the Epace 10, Marataoã and Pujante genotypes were used, obtained from the CCA/UFC/Active Germplasm Bank.

The seeds were disinfected by immersion in $70 \%(\mathrm{v} / \mathrm{v})$ alcohol solution, and agitated for 30 seconds, followed by two quick washes with distilled water. They were then Immediately immersed in $2.5 \% \quad(\mathrm{v} / \mathrm{v})$ sodium hypochlorite solution for 2 minutes, washed with distilled water and dried on paper towels. The seeds were then placed in rolls of paper towels $\left(\right.$ Germitest $\left.^{\circledR}\right)$, and moistened with saline solution in the proportion of 2.5 times the weight of the substrate. Based on the formula proposed by Richards (1954), the solutions were adjusted to concentrations of 0 (control), 1.5, 3.0, 4.5 and $6.0 \mathrm{dS}$ $\mathrm{m}^{-1}$ by diluting sodium chloride in distilled water.

For each treatment, 200 seeds were used, distributed in four rolls of paper of 50 seeds each. These were placed in a Biochemical Oxygen Demand (BOD) germination chamber at a constant temperature of $20,25,30$ and $35^{\circ} \mathrm{C}$ and a photoperiod of 12 hours. The first and final germination counts were taken on the fifth and eighth day respectively after setting up the test. The percentage of normal seedlings was determined using classification criteria established in the Rules for Seed Analysis (BRASIL, 2009).

An analysis of shoot and root growth in the seedlings was made eight days after starting the test, using four subsamples of 20 seeds for each treatment. From these, 10 seedlings were selected for measurement, which was carried out using a rule graduated in centimetres. The seedlings selected from each treatment were then placed in a forced air circulation oven at a constant temperature of $65^{\circ} \mathrm{C}$ for 72 hours and then weighed on a balance $(0.001 \mathrm{~g})$ to obtain the dry weight, with the result expressed in grams.seedling ${ }^{-1}$.

The experiment was conducted in a completely randomised design distributed in subdivided plots: three (genotypes) $\mathrm{x}$ four (temperatures) $\mathrm{x}$ five (salinity levels), with the temperature comprising the plot, salinity levels the subplots, and genotypes the sub-subplots. Each treatment consisted of four replications. The data were submitted to analysis of variance at a level of $5 \%$ significance, using the SISVAR $^{\circledR}$ statistical software (FERREIRA, 2000). For the variables that presented a significant difference, the regression model with the greatest fit and significance was selected using the TableCurve ${ }^{\circledR}$ v 5.01 software. The Sigmaplot v 12.5 software was used to graph the results. 


\section{RESULTS AND DISCUSSION}

The variables under analysis were significantly affected by the interaction between the factors of salinity level, temperature and genotype (Table 1).
The Pujante genotype was only affected by salinity when submitted to the temperature of $35^{\circ} \mathrm{C}$, presenting a linear reduction in germination in response to the increase in salinity levels. By checking the isolated effect of temperature, the temperatures of 20 and $25^{\circ} \mathrm{C}$ were seen to give the highest germination percentages, while the lowest values were obtained at 30 and $35^{\circ} \mathrm{C}$ (Figure 1).

Table 1. Analysis of variance for germination (G), first count (FC), shoot length (SL), root length (RL) and seedling dry weight (DW).

\begin{tabular}{cccccc}
\hline & \multicolumn{5}{c}{ Variable } \\
\hline SQRT & G & FC & SL & RL & DW \\
\hline Mean & $153.00^{* *}$ & $21.83^{* *}$ & $8.52^{* *}$ & $9.02^{* *}$ & $0.00003^{* *}$ \\
\hline CV1 (\%) & 58.00 & 16.00 & 11.34 & 15.28 & 0.124 \\
CV2 (\%) & 20.15 & 23.34 & 21.44 & 18.96 & 10.04 \\
CV3 (\%) & 6.89 & 5.62 & 6.53 & 5.91 & 5.20 \\
\hline
\end{tabular}

(**significant at $1 \%,{ }^{*}$ - significant at $5 \%$; ns - not significant).
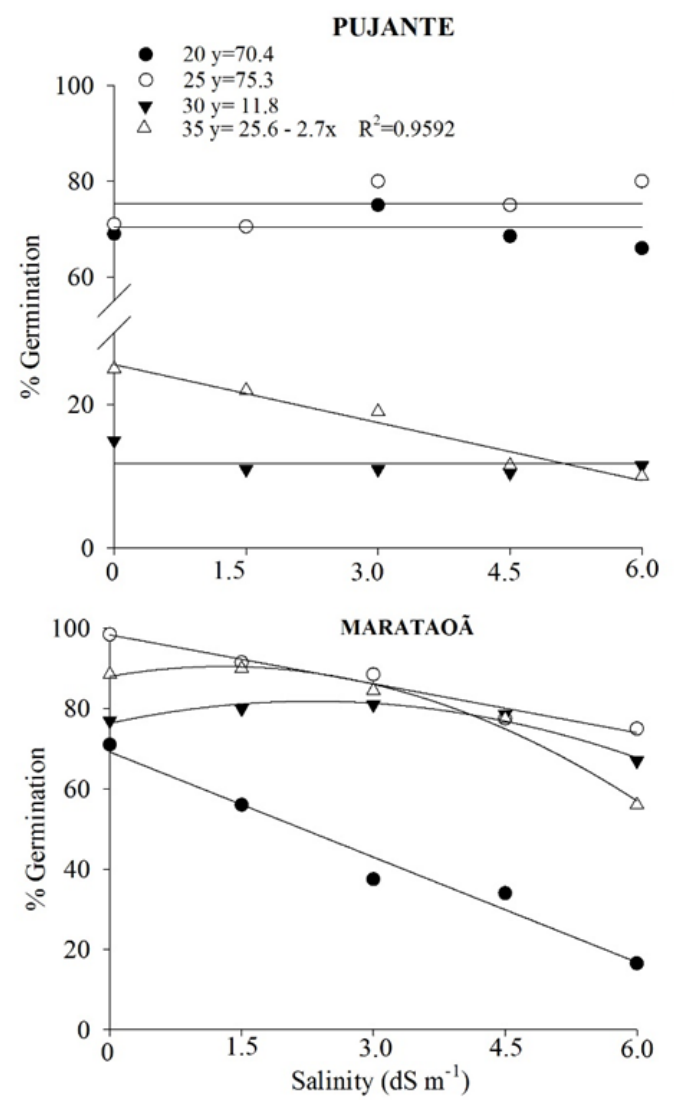

\section{EPACE 10}

- $20 \mathrm{y}=68.5744 /\{1+\exp [-(\mathrm{x}-5.9074) /-1.0473]\} \mathrm{R}^{2}=0.956^{*}$

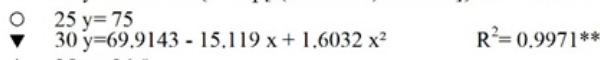

$\triangle \quad 35 \mathrm{y}=36.9$

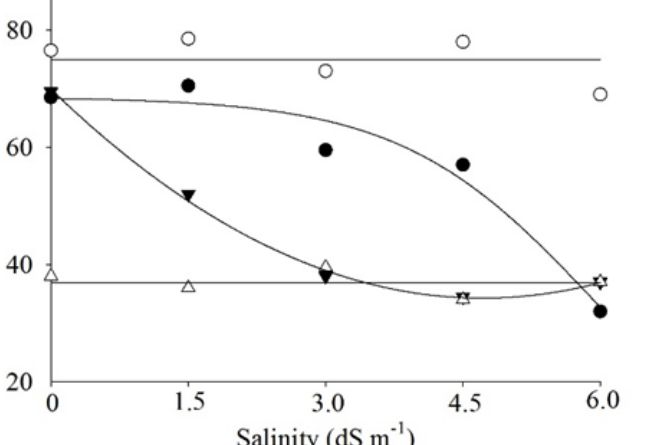

Salinity $\left(\mathrm{dS} \mathrm{m}^{-1}\right)$

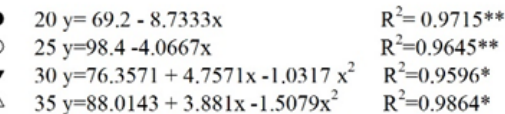

\begin{tabular}{lll}
$25 \mathrm{y}=98.4-4.0667 \mathrm{x}$ & $\mathrm{R}^{2}=0.9645^{* *}$ \\
\hline $\mathrm{R}$ & $\mathrm{y}=76.3571+4.7571 \mathrm{x}-1.0317 \mathrm{x}^{2}=0.9596^{*}$
\end{tabular}

$\triangle 35 \mathrm{y}=88.0143+3.881 \mathrm{x}-1.5079 \mathrm{x}^{2} \quad \mathrm{R}^{2}=0.9864 *$

Figure 1. Germination of cowpea genotypes at different salinity levels and temperatures.

In the absence of salt stress, the Epace 10 genotype showed higher germination percentages at temperatures of 20,25 and $30^{\circ} \mathrm{C}$; however, germination was only seen to stabilise at $25^{\circ} \mathrm{C}$, even with the increase in salinity. At $35^{\circ} \mathrm{C}$, there was no effect from salinity, possibly due to the low germination percentage. For the Marataoã genotype, a reduction in germination was seen at all temperatures together with the increases in salt concentration, with greater sensitivity at $20^{\circ} \mathrm{C}$.

Tolerance to salt stress and to the different temperatures show that genetic variability between genotypes is decisive for agricultural production, given the hardships found in the field. For the Pujante genotype, the optimal temperatures were 20 and $25^{\circ} \mathrm{C}$, whereas for the Epace 10 genotype it was 
$25^{\circ} \mathrm{C}$; at these temperatures, the genotypes displayed their maximum physiological potential, showing a higher tolerance to the salinity of the substrate.

The heat range considered optimal for the cowpea is between 20 and $30^{\circ} \mathrm{C}$ (CAMPOS; SILVA; SILVA, 2010). Accordingly, the best results found for germination were within the optimal range.

The Marataoã genotype maintained good germination (over $60 \%$ ) at temperatures of 25 to $35^{\circ} \mathrm{C}$, even with the increase in salinity levels; whereas the smallest values were seen at the temperature of $20^{\circ} \mathrm{C}$ due to the combination of heat stress caused by the low temperature (Figure 1).

These results agree with those of Deuner et al. (2011), who evaluated the germination of different genotypes of the black-eyed bean under the influence of salt stress and found that even when subjected to temperatures considered ideal $\left(25^{\circ} \mathrm{C}\right)$, the seeds, when induced at a salt stress of 150 and $200 \mathrm{mM}$ $\mathrm{NaCl}$ (equivalent to 15 and $20 \mathrm{dS} . \mathrm{m}^{-1}$ respectively), displayed a gradual reduction in germination, reaching values of less than $10 \%$ at the highest concentration under test for the Amendoim, Baio and Preto genotypes, and $15 \%$ for the Musqueado genotype. In the control treatment the mean value was around $93 \%$, maintaining these values up to the concentration of $100 \mathrm{mM} \mathrm{NaCl}$ (approximately 10 dS.m $\left.\mathrm{m}^{-1}\right)$.

For first germination count (Figure 2), it was also found that the effect of salinity and temperature varied according to each genotype. No significant effect from salinity was seen on the Pujante genotype, irrespective of temperature. However, the highest values for first count were seen at $25^{\circ} \mathrm{C}$, with the other temperatures displaying the lowest values that did not differ.

For the Epace 10 genotype, a reduction in this variable was seen starting from the concentration of $4.5 \mathrm{dS} \mathrm{m}^{-1}$ at all the temperatures under test. As seen for the Pujante genotype, the highest values were found at the temperature of $25^{\circ} \mathrm{C}$, and the lowest values at the other temperatures under study. For the Marataoã genotype, there was a decrease in first germination count for increases in salinity level at the temperatures of 25,30 and $35^{\circ} \mathrm{C}$, with the highest value being seen at the temperature of $25^{\circ} \mathrm{C}$, which was different from the other genotypes under study. The temperature of $20^{\circ} \mathrm{C}$ was not influenced by the level of salinity and presented the lowest values for first count.

\section{PUJANTE}
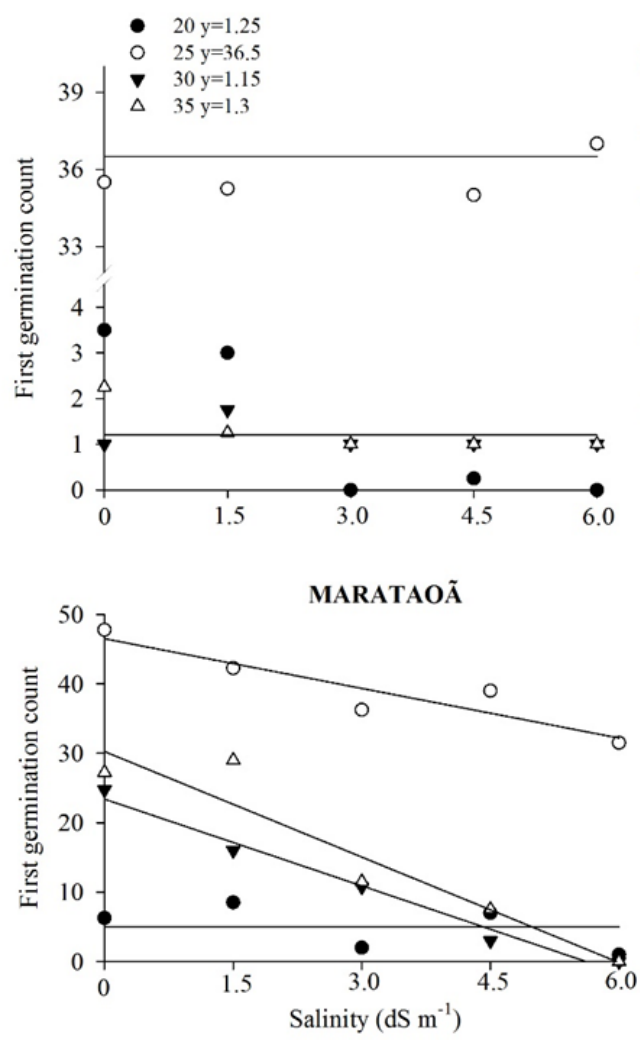

\section{EPACE 10}

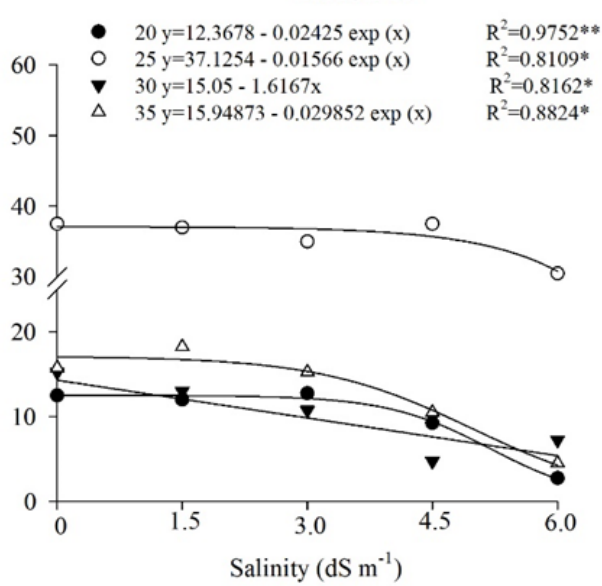

Figure 2. First germination count in cowpea genotypes at different salinity levels and temperatures. 
In the Epace 10 and Marataoã genotypes, the salinity caused a reduction in the values for first count. According to Marcos-Filho (2015), excess salts cause cytotoxicity and dehydration of the cells, reducing metabolic activity and the synthesis of new tissue in the seed due to low water availability. From these results, it can be seen that up to a concentration of $3.0 \mathrm{dS} \mathrm{m} \mathrm{m}^{-1}$, the Epace 10 genotype was not affected by the salinity, maintaining the values for first count; however, from $4.5 \mathrm{dS} \mathrm{m}^{-1}$, there was a reduction in these values at all the temperatures under test. Furthermore, the temperature of $25^{\circ} \mathrm{C}$ was the most suitable for this genotype, as shown by the germination. For the Marataoã genotype, at the temperatures of 25,30 and $35^{\circ} \mathrm{C}$, even at the lowest levels of salinity, there was a reduction in the values for first count. This may be due to a greater sensitivity of this genotype to the presence of salt. At the temperature of $20^{\circ} \mathrm{C}$, first germination count was not affected by the salinity, but presented the lowest values for the variable in question, in the same way as previously seen for germination.

Salt stress delayed germination in seeds of the black-eyed bean in the test for first germination starting from the concentration of $50 \mathrm{mM} \mathrm{NaCl}(5$ $\left.\mathrm{dS} . \mathrm{m}^{-1}\right)$. For this case, in the final evaluation, this treatment and the control had already stabilised; whereas at the concentrations of 150 and $200 \mathrm{mM}$ (15 and $20 \mathrm{dS} . \mathrm{m}^{-1}$ respectively) there were still no germinated seeds, demonstrating the negative effect of salt stress on this variable (DEUNER et al., 2011).

Temperature and salinity levels influenced shoot length in the genotypes under evaluation. The smallest seedlings were obtained at the temperature of $20^{\circ} \mathrm{C}$, with values of $5.16,5.5$ and 8.0 centimetres for Epace 10, Marataoã and Pujante respectively. Of these, only the first genotype maintained its growth as the salt concentration increased. For the other temperatures under test however, there was a reduction in length as salinity levels increased (Figure 3).

The temperature favoured shoot development in the seedlings. When the Pujante genotype was submitted to $30^{\circ} \mathrm{C}$, the values remained higher than those found at the other temperatures, irrespective of the level of salinity. Whereas, for the Epace 10 and Marataoã genotypes, this temperature was 25 to $30^{\circ} \mathrm{C}$, and 25 to $35^{\circ} \mathrm{C}$ respectively. These results agree with those presented by Nascimento et al. (2017) in seeds of the common bean of the Branca and Orelha de Vó cultivars, which obtained maximum shoot length at $30^{\circ} \mathrm{C}$.

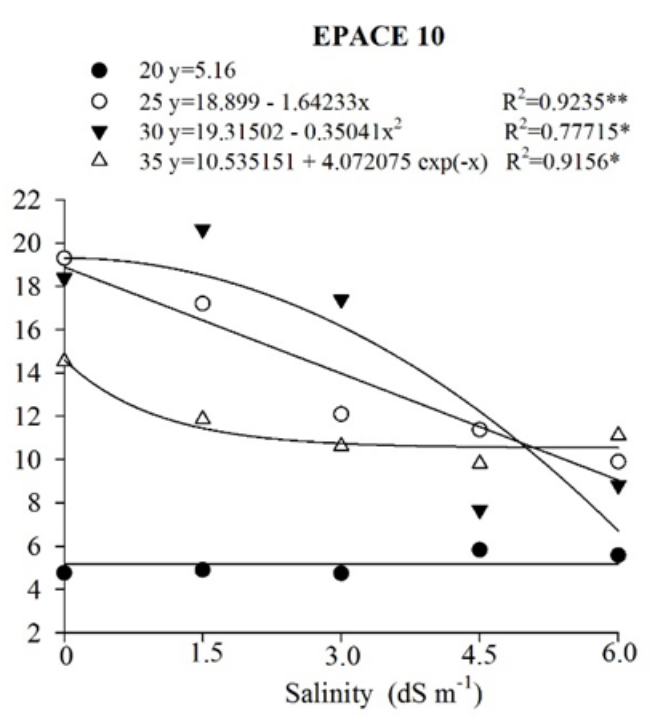

Salinity $\left(\mathrm{dS} \mathrm{m}^{-1}\right)$

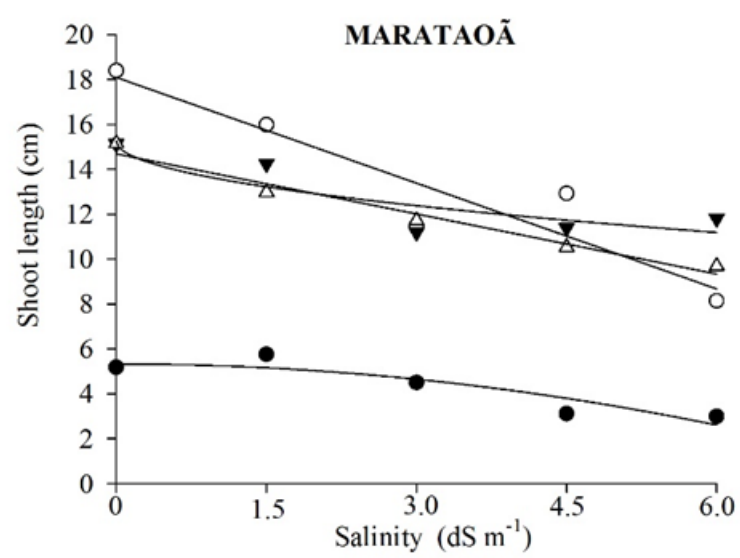

PUJANTE

- $20 \mathrm{y}=8.052-0.64866 \mathrm{x} \quad \mathrm{R}^{2}=0.8283^{*}$

○ $25 \mathrm{y}=13.395-0.1194 \mathrm{x}^{2} \quad \mathrm{R}^{2}=0.8942$ *

ק $30 \mathrm{y}=19.0475-0.846 \mathrm{x} \quad \mathrm{R}^{2}=0.9033^{*}$

$\triangle \quad 35 \mathrm{y}=13.8982-0.085 \mathrm{x}^{2} \quad \mathrm{R}^{2}=0.97 * *$

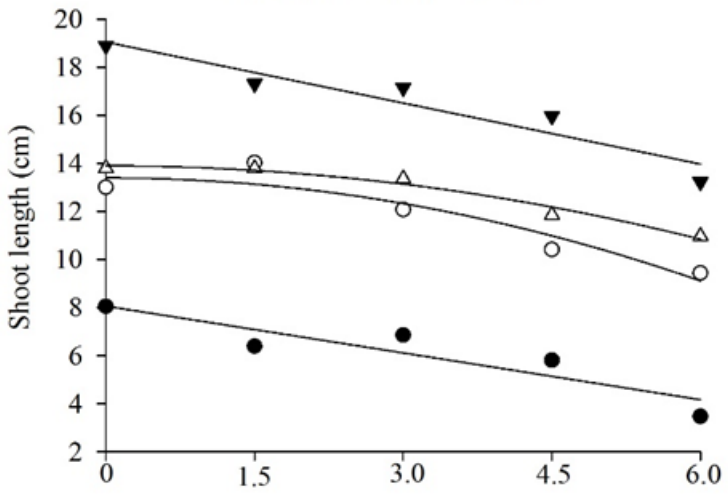

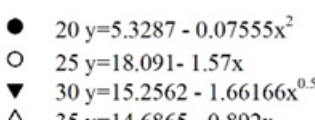

ק $\quad 25 \mathrm{y}=18.091-1.57 \mathrm{x}$
$\quad 30 \mathrm{y}=15.2562-1.66166 \mathrm{x}^{0}$

$\triangle \quad 35 \mathrm{y}=14.6865-0.892 \mathrm{x}$
$\mathrm{R}^{2}=0.8301^{*}$

$\mathrm{R}^{2}=0.8786^{*}$

$\mathrm{R}^{2}=0.7724^{*}$

$\mathrm{R}^{2}=0.9688^{*}$

Figure 3. Shoot length in seedlings of cowpea genotypes at different salinity levels and temperatures. 
Salt stress causes reduced seedling growth due to a reduction in water uptake and the poor translocation of reserves to the developing embryonic axis (PANDA; KHAN, 2009). The Pujante genotype proved to be tolerant up to a salinity level of $3.0 \mathrm{dS} \mathrm{m}^{-1}$, showing a reduction in growth at the other concentrations. For the Epace 10 and Marataoã genotypes, this decrease was more marked as the salt concentration increased. Similar results were obtained by Silva et al. (2011), also with the Epace 10 genotype.
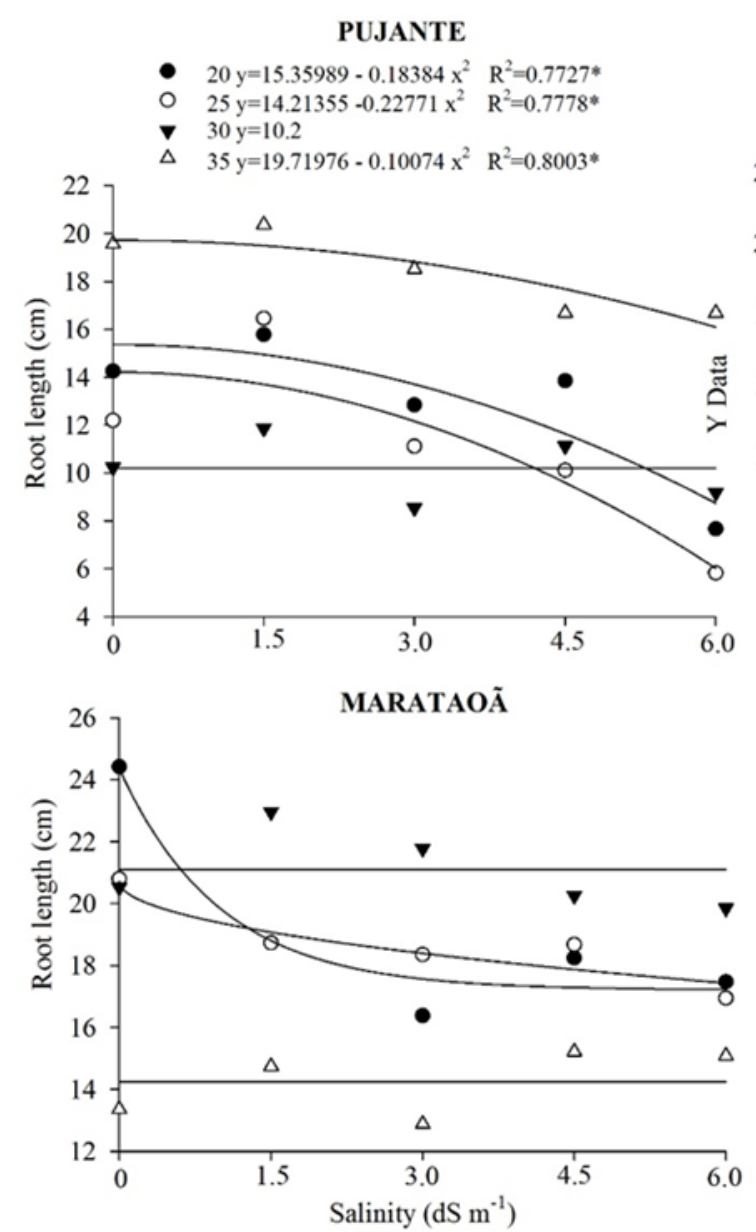

The factors under analysis affected root growth in the cowpea seedlings. For the Pujante genotype, the longest lengths occurred at $35^{\circ} \mathrm{C}$, where even at the highest level of salinity $\left(6.0 \mathrm{dS} \mathrm{m}^{-1}\right)$, these values were greater than those obtained with the control treatment at the other temperatures. The smallest lengths, of approximately 10.2 centimetres, were seen at $30^{\circ} \mathrm{C}$. For the Epace 10 and Marataoã genotypes, the longest and smallest root lengths were obtained at the temperatures of 30 and $35^{\circ} \mathrm{C}$ respectively (Figure 4 ).

EPACE 10

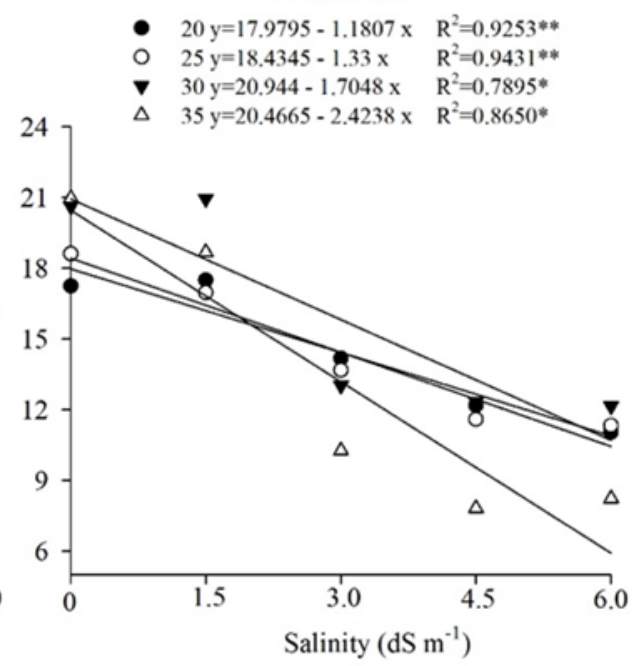

- $20 \mathrm{y}=17.21148+7.1415 \exp (-\mathrm{x}) \quad \mathrm{R}^{2}=0.9392^{* * *}$

- $25 \mathrm{y}=20.7181-1.3408 \mathrm{x}^{0.5} \quad \mathrm{R}^{2}=0.8680^{*}$

> $30 \mathrm{y}=21.1$

$\Delta \quad 35 \mathrm{y}=14.25$

Figure 4. Root length in seedlings of cowpea genotypes at different salinity levels and temperatures.

For the Pujante genotype, the temperatures of 25 and $35^{\circ} \mathrm{C}$ gave the highest values for root length when submitted to the salinity of $1.5 \mathrm{dS} \mathrm{m}^{-1}$, even higher than the control treatment and reducing as the salinity levels increased. At the temperatures of 20 and $30^{\circ} \mathrm{C}$, it was seen that the salinity caused an increase in root growth, reaching a maximum of 15 and $11.8 \mathrm{~cm}$ respectively at the level of $4.5 \mathrm{dS} \mathrm{m}^{-1}$.

Root length in the Epace 10 genotype was badly affected by the different salinity levels under test, showing a reduction from $1.5 \mathrm{dS} \mathrm{m}^{-1}$. In the Marataoã genotype at the temperatures of 20, 25 and $35^{\circ} \mathrm{C}$, the salinity also promoted an increase in root growth up to the level of $4.5 \mathrm{dS} \mathrm{m}^{-1}$, followed by a reduction; while at $30^{\circ} \mathrm{C}$, the level of $1.5 \mathrm{dS} \mathrm{m}{ }^{-1}$ limited development.

These results agree with those of Deuner et al. (2011), who observed seedlings of four bean genotypes (Amendoim, Baio, Mosqueado and Preto) and found a considerable difference in value between the control treatments and the induction of salt stress, with a constant fall in root length; when submitted to the concentration of $200 \mathrm{mM}\left(20 \mathrm{dS} . \mathrm{m}^{-1}\right) \mathrm{NaCl}$ only the beginning of primary root protrusion was noticeable. Maia et al. (2012) found that an increase in the external concentration of $\mathrm{NaCl}$ progressively reduced root length in the Pitiúba and Pérola cultivars, with reductions in the root system of $56 \%$ and $25 \%$ at the highest salt concentration $(\mathrm{NaCl} 100$ $\mathrm{mM}-10 \mathrm{dS} . \mathrm{m}^{-1}$ ) in relation to the respective 
controls. Dalchiavon, Neves and Haga (2016) also found a significant reduction in root growth in the bean, with values ranging from $11.9 \mathrm{~cm}$ for the control to $9.0 \mathrm{~cm}$ for the highest concentration of salt.

With seedling dry matter (Figure 5), better separation could be seen between the effects caused by the lowest and highest temperatures. In all the genotypes under study, the lowest temperatures (20 and $25^{\circ} \mathrm{C}$ ) displayed the highest values for dry weight, with the lowest values being obtained at the highest temperatures $\left(30\right.$ and $\left.35^{\circ} \mathrm{C}\right)$. The Pujante genotype showed a decrease in dry weight with

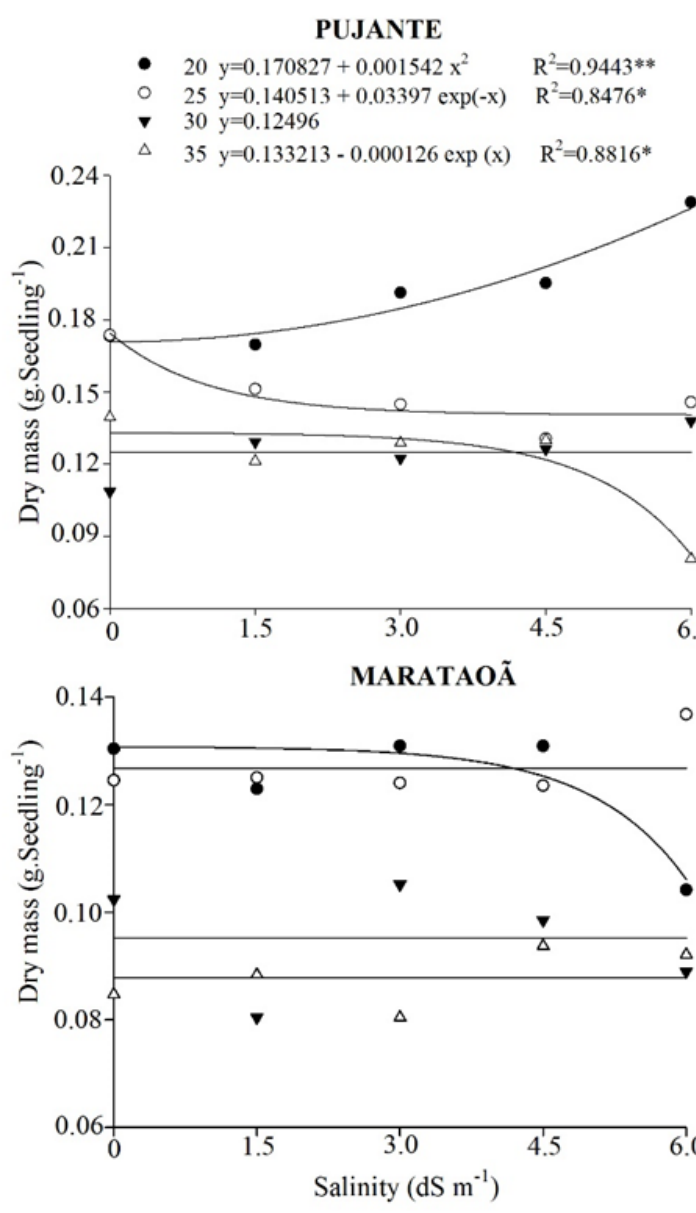

increased salinity at 25 and $35^{\circ} \mathrm{C}$, but at the temperature of $25^{\circ} \mathrm{C}$, the dry weight was greater than at $35^{\circ} \mathrm{C}$. On the other hand, there was an increase in dry weight at the temperature of $20^{\circ} \mathrm{C}$, showing that this genotype differed from the others at this temperature. Dry weight in the Epace 10 genotype was not influenced by salinity at the temperatures under test, with the highest results being found at the temperatures of 20 and $25^{\circ} \mathrm{C}$, and the lowest at 30 and $35^{\circ} \mathrm{C}$; similar results were found in the Marataoã genotype, where only the temperature of $20^{\circ} \mathrm{C}$ showed a decrease in dry weight starting from the concentration of $4.5 \mathrm{dS} . \mathrm{m}^{-1}$

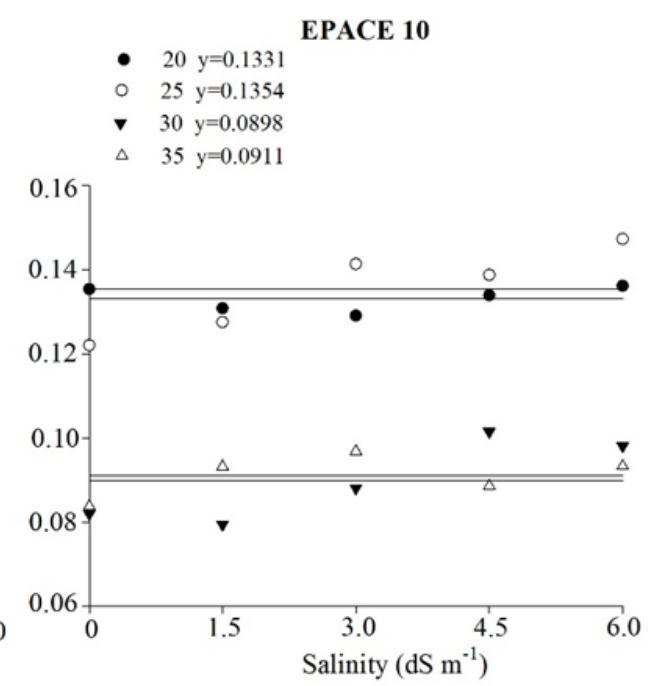

- $20 \mathrm{y}=0.13077-0.00006114 \exp (\mathrm{x}) \quad \mathrm{R}^{2}=0.8241^{*}$

- $25 \mathrm{y}=0.1268$

> $30 \mathrm{y}=0.0951$

$\Delta \quad 35 \mathrm{y}=0.0879$

Figure 5. Dry weight in seedlings of cowpea genotypes at different salinity levels and temperatures.

The results found for the Pujante genotype at the temperatures of 25 and $35^{\circ} \mathrm{C}$ agree with those of Dutra et al. (2011), who found a reduction in the dry weight of bean seedlings pre-treated with $\mathrm{NaCl}$ and induced at increasing temperatures, demonstrating that growth occurs due to the action of the salt and not to the increase in temperature. At the temperature of $20^{\circ} \mathrm{C}$, the Pujante genotype showed an increase in dry weight; this increase has also been reported by other authors, such as Panda and Khan (2009) working with Vigna radiata.

There was a reduction in dry-weight values in the Marataoã genotype at $20^{\circ} \mathrm{C}$, agreeing with the results of Bezerra et al. (2010), Lima et al. (2011); Coelho et al. (2013), who found a decrease in the dry weight of cowpea seedlings when submitted to the presence of salt. In the case of the Marataoã genotype, there was possible interaction between the low-temperature heat stress and the salt stress.

The Epace 10, Marataoã and Pujante genotypes showed similar behaviour for dry weight, with the greatest biomass production at the temperatures of 20 and $25^{\circ} \mathrm{C}$, and the lowest production at the temperatures of 30 and $35^{\circ} \mathrm{C}$. 


\section{CONCLUSION}

Germination and vigour in seeds of the cowpea can tolerate a salinity of around $3.0 \mathrm{dS} \mathrm{m} \mathrm{m}^{-1}$. The Pujante cultivar proved to be more tolerant to salt stress and more sensitive to heat stress, while 'Epace 10' and 'Marataoã' are more tolerant to heat stress and more sensitive to salt stress.

\section{REFERENCES}

AYERS, R. S.; WESTCOT, D. W. A qualidade de água na agricultura. 2 ed., Campina Grande, PB: UFPB, 1999. 153 p.

BEZERRA, A. K. P. et al. Rotação cultural feijão caupi/milho utilizando-se águas de salinidades diferentes. Ciência Rural, v. 40, n. 5, p. 1075-1082, 2010.

BRASIL. Ministério da Agricultura, Pecuária e Abastecimento. Regras para análise de sementes. Ministério da Agricultura, Pecuária e Abastecimento. Secretaria de Defesa Agropecuária. Brasília, DF: Mapa/ACS, 2009. 395 p.

CALVET, A. S. F. et al. Crescimento e acumulação de solutos em feijão-caupi irrigado com águas de salinidade crescente em diferentes fases de desenvolvimento. Irriga, v. 18, n. 1, p. 148-159, 2013.

CAMPOS, J. H. B.; SILVA, M. T.; SILVA, V. P. R. Impacto do aquecimento global no cultivo do feijãocaupi, no Estado da Paraíba. Revista Brasileira de Engenharia Agrícola e Ambiental, v. 14, n. 4, p. 396-404, 2010.

COELHO, J. B. M. et al. Comportamento hídrico e crescimento do feijão vigna cultivado em solos salinizados. Revista Brasileira de Engenharia Agrícola e Ambiental, v. 17, n. 4, p. 379-385, 2013.

DALCHIAVON, F. C.; NEVES, G.; HAGA, K. I. Efeito de stresse salino em sementes de Phaseolus vulgaris. Revista de Ciências Agrárias, v. 39, n. 3, p. 404-412, 2016.

DEUNER, C. et al. Viabilidade e atividade antioxidante de sementes de genótipos de feijãomiúdo submetidos ao estresse salino. Revista Brasileira de Sementes, v. 33, n. 4, p. 711-720, 2011.

DUTRA, A. T. B. et al. Temperaturas elevadas afetam a distribuição de íons em plantas de feijão caupi pré-tratadas com $\mathrm{NaCl}$. Revista Brasileira de Engenharia Agrícola e Ambiental, v. 15, n. 4, p.
403-409, 2011

ESTEVES, B. S.; SUZUKI, M. S. Efeito da salinidade sobre as plantas. Oecologia Australis, v. 12, n. 4, p. 662-679, 2008.

FERREIRA, A. C. T. et al. Water and salt stresses on germination of cowpea (Vigna unguiculata cV. BRS Tumucumaque) seeds. Revista Caatinga, v. 30, n. 4, p. 1009-1016, 2017.

FERREIRA, D. F. Análises estatísticas por meio do Sisvar para Windows versão 4.0. In: REUNIÃO ANUAL DA REGIÃO BRASILEIRA DA SOCIEDADE INTERNACIONAL DE BIOMETRIA, 45., 2000, São Paulo. Anais...São Carlos, SP: SIB, 2000, p. 255-258.

FREIRE FILHO, F. R. et al. Feijão-caupi no Brasil: produção, melhoramento genético, avanços e desafios. 1 ed. Teresina, PI: Embrapa Meio-Norte, 2011. 84 p.

LIMA, M. A. et al. Aplicação de silício em milho e feijão-de-corda sob estresse salino. Revista Ciência Agronômica, v. 42, n. 2, p. 398-403, 2011.

MAIA, J. M. et al. Atividade de enzimas antioxidantes e inibição do crescimento radicular de feijão caupi sob diferentes níveis de salinidade. Acta Botânica Brasílica, v. 26, n. 2, p. 342-349, 2012.

MARCOS-FILHO, J. Fisiologia de sementes de plantas cultivadas. 2. ed., Londrina, PR: ABRATES, 2015. 660 p.

MOTERLE, L. M. et al. Influência do estresse hídrico sobre o desempenho fisiológico de sementes de híbridos simples de milho-pipoca. Ciência e Agrotecnologia, v. 32, n. 6, p. 1810-1817, 2008.

NASCIMENTO, M. G. R. et al. Lima bean (Phaseolus lunatus L.) seeds exposed to different salt concentrations and temperatures. Revista Caatinga, v. 30, n. 3, p. 738-747, 2017.

OLIVEIRA, F. de A. et al. Estresse salino e biorregulador vegetal em feijão caupi. Irriga, v. 22, n. 2 , p. $314-329,2017$.

PANDA, S. K.; KHAN, M. H. Growth, oxidative damage and antioxidant responses in greengram (Vigna radiata L.) under short-term salinity stress and its recovery. Journal of Agronomy \& Crop Science, v. 195, n. 6, p. 442-454, 2009.

SILVA, F. L. B. et al. Interação entre salinidade e biofertilizante bovino na cultura do feijão-caupi. Revista Brasileira de Engenharia Agrícola e Ambiental, v. 15, n. 4, p. 383-389, 2011. 
SOUZA, M. D. M. et al. Efeito da adubação potássica no crescimento do feijão de corda preto. Revista Brasileira de Agricultura Irrigada, v. 7, n. 1, p. 66-73, 2013.

TAIZ, L. et al. Fisiologia e desenvolvimento vegetal. 6. ed., Porto Alegre, RS: Artmed, 2017. 888 p. 